\title{
Interannual Variability of Summertime Convective Cloudiness and Precipitation in the Central Andes Derived from ISCCP-B3 Data
}

\author{
Mathias Vuille And Frank Keimig \\ Climate System Research Center, Department of Geosciences, University of Massachusetts, Amherst, Amherst, Massachusetts
}

(Manuscript received 15 September 2003, in final form 22 March 2004)

\begin{abstract}
The interannual variability of austral summer [December-January-February-March (DJFM)] convective activity and precipitation in the central Andes $\left(15^{\circ}-30^{\circ} \mathrm{S}\right)$ is investigated between 1983 and 1999 based on in situ rain gauge measurements, International Satellite Cloud Climatology Project (ISCCP) reduced radiance satellite data (the B3 dataset), and National Centers for Environmental Prediction-National Center for Atmospheric Research (NCEP-NCAR) reanalysis data.

Twice-daily ISCCP-B3 calibrated infrared data, corrected for limb-darkening effects and representing equivalent blackbody temperatures $T_{b}$ emitted by clouds are used to derive seasonal composites of fractional cold cloud coverage $F^{*}$. Comparison of in situ rain gauge measurements with $F^{*}$ show a good correlation when a temperature threshold $T_{b}=240 \mathrm{~K}$ is used to derive $F^{*}$. A rotated empirical orthogonal function (REOF) applied to the seasonal estimates of $F^{*}$ yielded three spatially separated modes of convective activity in the south, northwest, and northeast of the central Andes.

Results indicate that precipitation variability in the central Andes shows less spatial coherence than previously thought, with many years showing an antiphasing of wet/dry conditions between the northern and southern part of the study area. Regression analyses confirm the crucial role of both intensity and location of upper-air circulation anomalies with easterly wind anomalies favoring wet conditions, and westerly winds producing dry conditions. Two different forcing mechanisms are identified as main causes of upper-air zonal wind anomalies in the northern and southern part of the central Andes, respectively. Easterly wind anomalies during wet summers in the northern part are in geostrophic balance with reduced meridional baroclinicity due to low-latitude (midlatitude) cooling (warming), consistent with earlier studies. Farther to the south, easterly wind anomalies during wet summers are the result of an upper-air anticyclonic anomaly centered over southeastern South America, leading to a relaxation of the upper-air westerly winds and episodic easterly transport of humid air toward the subtropical Andes. This pattern is similar to one of the leading modes of intraseasonal variability, related to extratropical Rossby wave dispersion and modulation of the position of the Bolivian high.

Correlation analysis of $F^{*}$ with near-surface specific humidity reveals that humidity variations in the lowlands to the east are not relevant on interannual time scales for the more humid northern part of the Altiplano. In the southern Altiplano, however, there is a significant correlation between convective activity and precipitation at high elevation and the low-level humidity content to the southeast of the Andes.
\end{abstract}

\section{Introduction}

The central Andes, located between $10^{\circ}$ and $30^{\circ} \mathrm{S}$, separate the humid environments of the Amazon and Chaco basins to the east from the arid Atacama Desert influenced by the southeast Pacific anticyclone to the west. The high Andes and the inter-Andean plateau (Altiplano, located at $\sim 3800 \mathrm{~m}$ ) receive precipitation almost exclusively during austral summer (DecemberMarch), associated with the seasonal expansion of the upper-air easterlies and related near-surface moisture influx from continental lowlands to the east. Precipitation from the west is rare because Pacific moisture is trapped vertically by large-scale subsidence and a stable low-

Corresponding author address: Dr. Mathias Vuille, Climate System Research Center, Dept. of Geosciences, University of Massachusetts, Amherst, 611 North Pleasant Street, Amherst, MA 01003.

E-mail: mathias@geo.umass.edu level inversion at $\sim 900 \mathrm{hPa}$, and laterally by the coastal escarpment.

This easterly moisture source was first suggested by Kessler $(1974,1981)$ and later confirmed by Fuenzalida and Rutllant (1987) based on an analysis of the atmospheric circulation. Subsequent studies employing onsite observations (Aceituno and Montecinos 1997; Hardy et al. 1998), transit-time and trajectory analyses (Vuille et al. 1998), radiosonde data (Aceituno and Montecinos 1993; Vuille 1999), and mesoscale (Garreaud 1999) and stable isotope modeling (Vuille et al. 2003) further corroborated these initial results.

Consistent with this easterly moisture source, annual precipitation amounts decrease significantly from east to west (Fig. 1a). On average $600-1000 \mathrm{~mm}$ of precipitation fall annually along the eastern cordillera, while the annual mean along the western rim of the Andes only amounts to $50-400 \mathrm{~mm}$. Along the Pacific coast, 

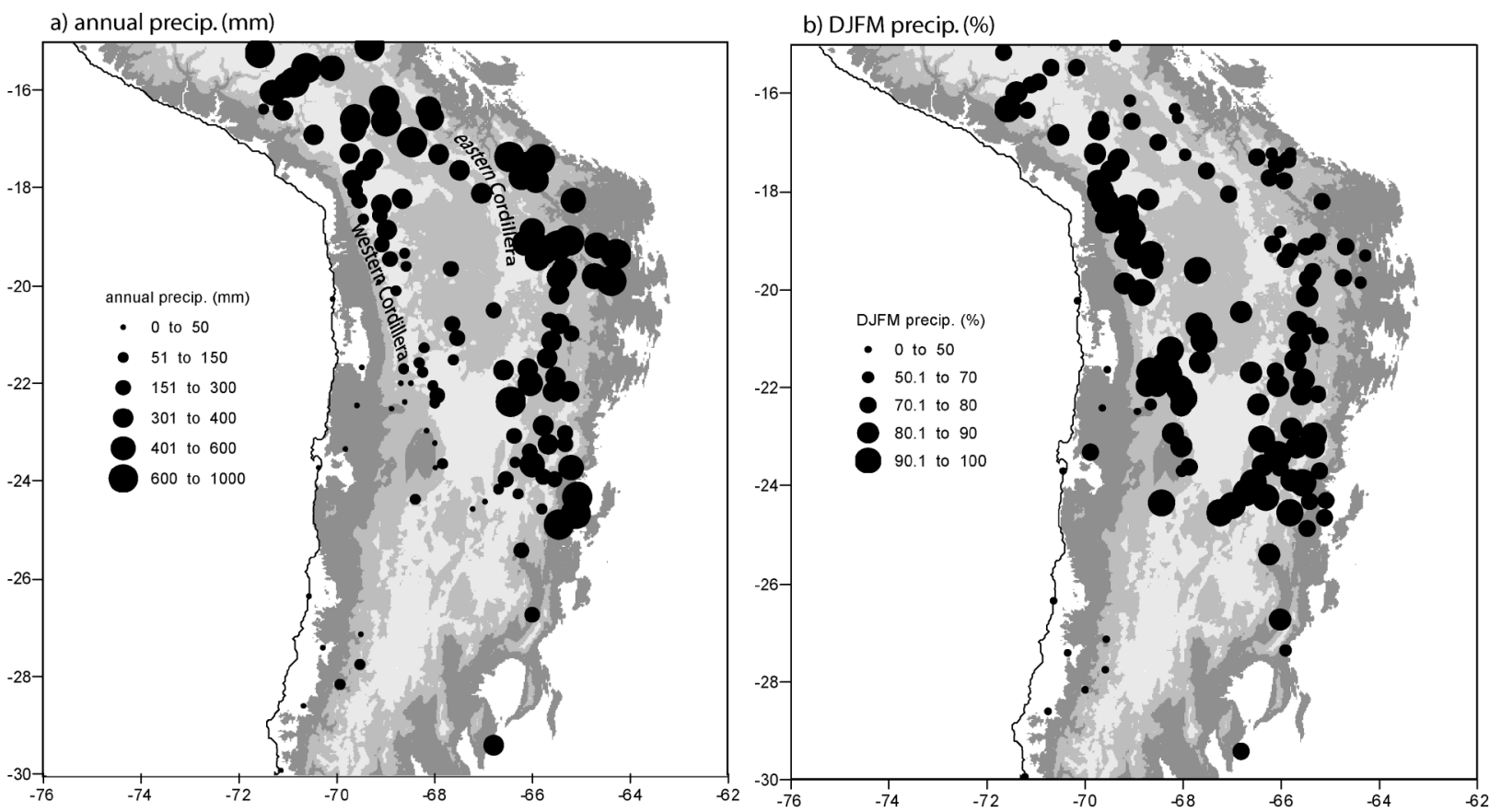

FIG. 1. (a) Long-term annual mean precipitation amount $(\mathrm{mm})$ and (b) percent precipitation in DJFM of the annual total in the central Andes. To the east of the Andes only rain gauge data $>1500 \mathrm{~m}$ are shown. Shading indicates elevation zones above $1000 \mathrm{~m}$ (dark gray), $2500 \mathrm{~m}$ (medium gray), and $4000 \mathrm{~m}$ (light gray). Record lengths of individual stations vary.

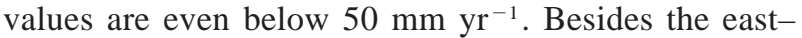
west gradient, there is also a significant decrease in precipitation from north to south, in particular along the western slopes of the central Andes, consistent with a tropical moisture source (Fig. 1a). Along the eastern slope this decrease is less obvious and precipitation amounts even increase slightly around $24^{\circ} \mathrm{S}$. Presumably a second more southeasterly moisture source contributes to precipitation in this area.

Figure $1 \mathrm{~b}$ shows the fraction of annual precipitation (in \%), which falls during the main rainy season December-January-February-March (DJFM). Except for the coastal stations and the extreme southwest (south of $26^{\circ} \mathrm{S}$ ), which receives the majority of its precipitation during austral winter (Vuille and Ammann 1997), the entire central Andes receive more than 50\% of their annual precipitation during these four summer months. Over the interior and western parts of the Altiplano, summer precipitation even accounts for $80 \%-90 \%$ of the annual total. Along the eastern slopes of the Andes the number is somewhat lower $(50 \%-80 \%)$ because the rainy season starts earlier (in October or November) and lasts until April.

Precipitation variability on all time scales from intraseasonal to glacial-interglacial appears to be predominantly controlled by the the upper-air circulation (Garreaud et al. 2003). In general upper-air easterly zonal flow tends to increase precipitation in the central Andes, because the upper-air easterlies, through turbulent entrainment and downward mixing of easterly momentum, will enhance near surface moisture influx from the east
(Garreaud 1999). Seasonal, intraseasonal, and interannual variability in convective rainfall seems to be controlled by this near-surface water vapor influx from the continental lowlands to the east of the central Andes. Observational studies indicate that without this moist air influx the mixing ratio in the central Andes remains too low for deep moist convection. Conversely a westerly upper-air zonal flow will lead to enhanced nearsurface westerly winds. Since these air masses originate over the Pacific above the inversion layer and the coastal desert of northern Chile, the mixing ratio will remain below the necessary threshold for deep convection. The positioning and intensity of the Bolivian high plays a crucial role in controlling this upper-air circulation over the central Andes, with a more southerly (northerly) position favoring enhanced easterly (westerly) flow and hence increased (reduced) precipitation (Aceituno and Montecinos 1993; Vuille 1999; Lenters and Cook 1999).

Precipitation variability in the central Andes is particularly pronounced on interannual time scales, and there is general agreement that a significant fraction of this variability can be attributed to ENSO, with below (above) average precipitation during El Niño (La Niña) events (Thompson et al. 1984; Aceituno 1988; Lenters and Cook 1999; Vuille 1999; Vuille et al. 2000a; Arnaud et al. 2001; Garreaud and Aceituno 2001; Wagnon et al. 2001; Bradley et al. 2003; Francou et al. 2003). Wet summers on the Altiplano are associated with a La Niña-related cooling of the tropical Pacific and the tropical troposphere and resulting weakened westerly flow aloft the central Andes in response to reduced meridi- 
onal baroclinicity at subtropical latitudes (Garreaud and Aceituno 2001). The reverse happens during an El Niño-related warming of the tropical Pacific.

Despite all this recent progress in our understanding of climate variability in the central Andes, several issues remain unresolved. In particular it is unclear as to how the spatial signature of precipitation variability on interannual and longer time scales varies throughout the central Andes. Vuille et al. (2000a), based on a principal component analysis (PCA) of Altiplano rain gauge data, identified three spatially separated modes of interannual precipitation variability. Their results suggested that there may not be as much spatial coherence in precipitation throughout the central Andes as previously thought, but the significance of the results was limited by the low station density and the rather poor quality of the available precipitation network. Unfortunately, as shown in Fig. 1, high-elevation rain gauge data is almost nonexistent south of $24^{\circ} \mathrm{S}$.

Due to this lack of information it is often assumed that precipitation over the entire central Andes varies in phase on interannual and longer time scales, including over the southern part where little to no information is available. This assumption has sparked considerable debate in the paleoclimate community because there is growing evidence for discrepancies in the timing and extent of past humid and dry phases in different parts of the central Andes (e.g., Baker et al. 2001; Betancourt et al. 2000; Grosjean et al. 2003; Seltzer et al. 2003; Thompson et al. 1998). While these inconsistencies are usually attributed to dating problems, false interpretations, or different response times and sensitivities of different climate proxies, it is also possible that some of the observed incoherencies in the fossil record may be related to the geographic complexity of the regional climate. This view is supported by a simple exercise, comparing the interannual variability of summer precipitation from two rain gauge stations in the eastern Altiplano (Oruro, $18.05^{\circ} \mathrm{S}, 67.07^{\circ} \mathrm{W} ; 3706 \mathrm{~m}$ ) and on the western Andean slope (San Pedro de Atacama, $22.92^{\circ} \mathrm{S}, 68.20^{\circ} \mathrm{W} ; 2450 \mathrm{~m}$ ) of the central Andes (Fig. 2). Clearly there is no significant correlation between the two records and not even the driest and wettest years coincide between the two stations. Of the five wettest summers in Oruro (uppermost quartile), not one reached this category in San Pedro de Atacama, and one summer even turned out to belong to the driest category (lowermost quartile). On the other hand, two of the five most humid summers in San Pedro de Atacama belong to the driest category in the Oruro record, and not one qualifies for the uppermost quartile. A similar lack of coherence is apparent when the driest years are compared between the two stations.

The intent of this paper is thus to investigate the spatial variability of austral summer precipitation on interannual time scales over the entire central Andes. Do precipitation amounts always vary in phase over the entire Andean range on interannual time scales or are

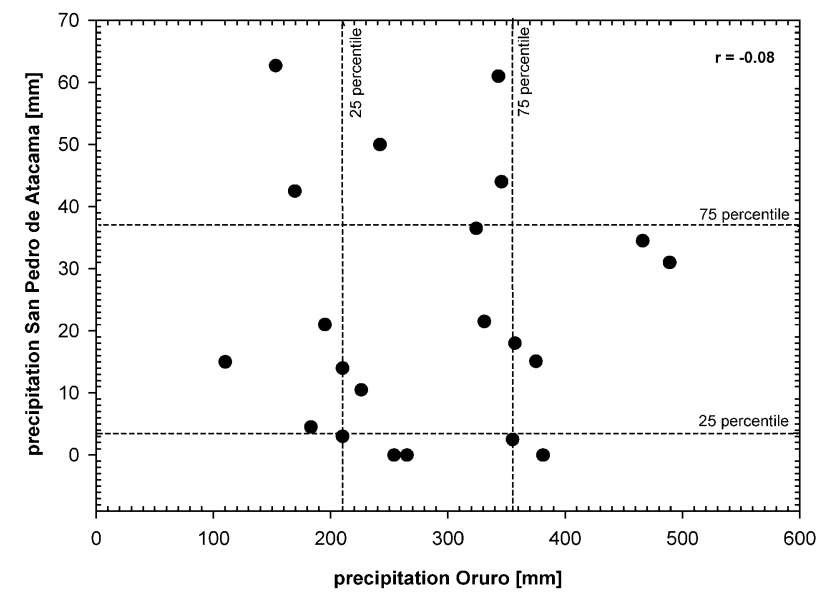

FIG. 2. Scatterplot of DJFM precipitation $(\mathrm{mm})$ in Oruro $\left(18.05^{\circ} \mathrm{S}\right.$, $\left.67.07^{\circ} \mathrm{W} ; 3706 \mathrm{~m}\right)$ vs San Pedro de Atacama $\left(22.92^{\circ} \mathrm{S}, 68.20^{\circ} \mathrm{W} ; 2450\right.$ m) between 1966/67 and 1988/89. Dashed lines indicate the upper and lower quartiles of both records.

there several different modes of precipitation variability, as suggested by the comparison of rain gauge data from Oruro and San Pedro de Atacama (Fig. 2)? If the later is indeed true, is the spatial incoherence caused by different forcing mechanisms or different moisture sources or are even other factors at play?

Even though such a study on interannual variability cannot resolve the apparent discrepancies between paleorecords, which are influenced by centennial-to-millennial-scale variations, it might provide support for the view that differing results from the fossil record in different parts of the central Andes need not necessarily be inconsistent.

Because spatially complete information at high resolution is of crucial importance to answer these questions, we rely on satellite-derived cloud cover data as a proxy for precipitation. We use reduced resolution radiance images [the B3 data from the International Satellite Cloud Climatology Project; see Rossow and Schiffer 1991, 1999] because it provides for a spatially complete dataset with high spatial and temporal resolution and it covers a long enough time period (1983-99) to investigate interannual variability. Most importantly, however, a previous study by Garreaud and Wallace (1997) shows that the fractional cold cloud coverage derived from the B3 data serves as a good proxy for convective activity in the central Andes during the summer months. We even extend this interpretation to directly relate fractional cold cloud coverage to precipitation amount (see section 3). In the next section we present the data and methods we applied. Section 3 explores both the spatial and temporal relationship between fractional cold cloud coverage using varying temperature thresholds and precipitation from rain gauge measurements. Section 4 shows the results of a rotated empirical orthogonal function (REOF) analysis applied on the fractional cold cloud coverage, discusses the de- 
rived modes of convective activity and precipitation, and links these main modes with the large-scale atmospheric circulation. Section 5 ends with a summary and some concluding remarks.

\section{Data and methods}

Several satellite-derived products are available to study tropical convection and a number of methods and algorithms have been developed to estimate precipitation using visible, infrared and microwave imagery. The most commonly used products are outgoing longwave radation (OLR; e.g., Liebmann et al. 1998), the Geostationary Operational Environmental Satellite (GOES) Precipitation Index (GPI; e.g., Arkin and Meisner 1987; Morrissey and Greene 1993; Joyce and Arkin 1997), the Special Sensor Microwave Imager (SSM/I; e.g., Negri et al. 1994, 2000) and data from the Tropical Rainfall Measuring Mission (TRMM; e.g., Adler et al. 2000; Bendix et al. 2003). Some products, such as the Global Precipitation Climatology Project (GPCP) and the Climate Prediction Center (CPC) Merged Analysis of Precipitation (CMAP) have combined information from satellite and rain gauge data (e.g., Arkin and Xie 1994; Ebert et al. 1996; Huffman et al. 1997; Xie and Arkin 1997). While all of these datasets have their advantages and their limitations, none of them are very well suited for our purpose because of inadequate spatial resolution (OLR, GPI, GPCP, CMAP), temporal sampling (SSM/I, TRMM), or because of a too short record length (SSM/I, TRMM). Instead we used data from the International Satellite Cloud Climatology Project (ISCCP), which has been monitoring cloud properties at mesoscale resolution for almost $20 \mathrm{yr}$ (see Rossow and Schiffer 1999 for a review of available products). A number of studies have compared cloud data from ISCCP with satellitederived or rain gauge-based estimates of precipitation (e.g., Marengo 1995; McCollum and Krajewski 1999; Todd and Washington 1999). Here we use ISCCP Stage B3 data, a set of reduced volume infrared and visible radiance images from the GOES, National Oceanic and Atmospheric Administration (NOAA), Geostationary Meteorological Satellite (GMS) and Meteosat satellites. The B3 dataset is a compressed version of the original data with a resolution of $30 \mathrm{~km}$, every $3 \mathrm{~h}$ (eight images per day, beginning at 0000 UTC) and is currently available for the time period 1983-99. We use the calibrated values from the infrared $(11.6 \mu \mathrm{m})$ dataset, representing equivalent blackbody temperatures $T_{b}$ emitted by clouds. Because the emitted temperature $T_{b}$ at the cloud top is directly proportional to the height of the cloud top, it can be viewed as a measure of convective activity. Garreaud and Wallace (1997) successfully used this dataset to study the diurnal cycle of convective activity over the tropical Americas, with a special emphasis on the central Andes. In section 3 we show that the seasonal fractional cold cloud coverage derived from the original data is not only a good measure of convective activity,
TABLE 1. Satellite data used in this study.

\begin{tabular}{llc}
\hline \hline \multicolumn{1}{c}{ Time period } & Satellite & Subsatellite lon \\
\hline Dec 1983-Mar 1984 & GOES-5 & $75^{\circ} \mathrm{W}$ \\
Dec 1984-Mar 1987 & GOES-6 & $97^{\circ}-109^{\circ} \mathrm{W}$ \\
Dec 1987-Mar 1992 & GOES-7 & $74^{\circ}-111^{\circ} \mathrm{W}$ \\
Dec 1992-Mar 1995 & Meteosat-3 & $69^{\circ}-75^{\circ} \mathrm{W}$ \\
Dec 1995 & GOES-7 & $135^{\circ} \mathrm{W}$ \\
Jan 1996-Mar 1999 & GOES-8 & $74^{\circ}-75^{\circ} \mathrm{W}$ \\
\hline
\end{tabular}

but can be used directly as a reasonably good estimate of precipitation.

From the 3-hourly global datasets we extracted all available images for the months December to March between 1983 and 1999. Table 1 lists the satellites used in this study with their corresponding sublongitudes. For overlapping time periods when information from several satellites was available, we used data from the satellite with the smallest zenith angle (the one for which the longitudinal distance between satellite sublongitude and the central Andes is the least). Nonetheless variations in zenith angle lead to a considerable bias of the equivalent brightness temperature $T_{b}$ recorded by the satellite, with $T_{b}$ being increasingly colder at locations farther away from the satellite nadir point (Joyce et al. 2001; Janowiak et al. 2001). This effect, known as limb darkening, is due to increased obstruction of radiation emitted from the earth's surface by the sides of clouds with increasing zenith angle (geometric effect) and the longer optical path, which increases attenuation and emission by cloud matter and water vapor (radiative effect). We used the technique developed by Joyce et al. (2001) to adjust for this bias in each individual pixel of all images used. Comparison of the final seasonal (DJFM) composites, indicating the fraction of days $F^{*}$ with cold cloud coverage below $240 \mathrm{~K}$ (see section 3 ), with and without adjusting for this limb-darkening effect, shows that the fraction of days $F^{*}$ with cold cloud coverage is reduced between $1 \%$ and $12 \%$ over the central Andes once such a correction is applied. The changes depend on the subsatellite longitude, the location of the pixel and its brightness temperature $T_{b}$, and are largest for large zenith angles and temperatures around $230 \mathrm{~K}$.

Each corrected image was subsequently geocoded and resampled into a new $0.33^{\circ}$ latitude $\times 0.33^{\circ}$ longitude grid, by averaging all pixel values located within each grid cell. Subsets over the domain $15^{\circ}-30^{\circ} \mathrm{S}, 76^{\circ}-62^{\circ} \mathrm{W}$ were extracted from each image for further processing. The choice of the grid-size resolution is a compromise between achieving the highest possible spatial resolution and still maintaining a coarse enough resolution to guarantee pixel information in almost all grid cells. Our resolution is thus considerably finer than that in the study by Garreaud and Wallace (1997), who used a $0.5^{\circ}$ latitude $\times 0.5^{\circ}$ longitude grid. A number of days are missing in the B3 dataset, which together with the highresolution resampling occasionally resulted in grid cells without information. However, since our analysis is 
TABle 2. Percentage of days with data available at either 0000 or 2100 UTC (averaged over all grid cells) between Dec and Mar in each year.

\begin{tabular}{cc}
\hline \hline Year & $\%$ \\
\hline $1983 / 84$ & 98 \\
$1984 / 85$ & 91 \\
$1985 / 86$ & 90 \\
$1986 / 87$ & 92 \\
$1987 / 88$ & 75 \\
$1988 / 89$ & 90 \\
$1989 / 90$ & 95 \\
$1990 / 91$ & 98 \\
$1991 / 92$ & 97 \\
$1992 / 93$ & 97 \\
$1993 / 94$ & 89 \\
$1994 / 95$ & 98 \\
$1995 / 96$ & 77 \\
$1996 / 97$ & 92 \\
$1997 / 98$ & 82 \\
$1998 / 99$ & 95 \\
\hline
\end{tabular}

based on seasonal averages this should not affect the outcome of the results. As shown in Table 2 all summers were at least $75 \%$ complete and only in $3 \mathrm{yr}(1987 / 88$, $1995 / 96$, and 1997/98) were data available less than $89 \%$ of the time (averaged over all grid cells).

Summertime convection and precipitation in the central Andes occurs almost exclusively in the late afternoon and early evening hours, presumably related to favorable thermodynamic conditions (Fuenzalida and Rutllant 1987; Garreaud and Wallace 1997). Figure 3 illustrates this behavior based on the diurnal cycle of convective activity (fraction of days with $T_{b}<235 \mathrm{~K}$ ) along the Altiplano at $68^{\circ} \mathrm{W}$ between $15^{\circ}$ and $30^{\circ} \mathrm{S}$. Since cold convective clouds occur with a frequency of less than $2 \%$ (i.e., only on 2-3 days per summer) between midnight and early afternoon, and we are only interested in knowing whether rain producing convective activity occurs on any given day, but not at which time of the day, we only used twice-daily data (2100 and 0000 UTC, corresponding to 1700 and 2000 local time in the central Andes). It is only north of $16^{\circ} \mathrm{S}$, as one descends along the northeast slopes of the Andes, where this characteristic changes and convective activity suddenly exhibits a more equally distributed diurnal cycle with an early morning maximum (see Fig. 3). Therefore our analysis is restricted to the southern part of the central Andes (south of $15^{\circ} \mathrm{S}$ ) and to the higher elevations $(>3000 \mathrm{~m}$ along the northeast slopes and $>1500$ $\mathrm{m}$ elsewhere).

From the twice-daily data seasonal (DJFM) composites, indicating the fraction of days $F^{*}$ with cold cloud coverage below a given temperature threshold $T_{b}^{*}$, at either 2100 or 0000 UTC were produced. The value $F^{*}$ thus describes the number of days (in \%) per season when the cloud-top temperature $T_{b}$ dropped below a given threshold at either 2100 or 0000 UTC. The commonly used threshold for convective activity $T_{b}^{*}$ is 235 K (Arkin and Meisner 1987). However, since we were

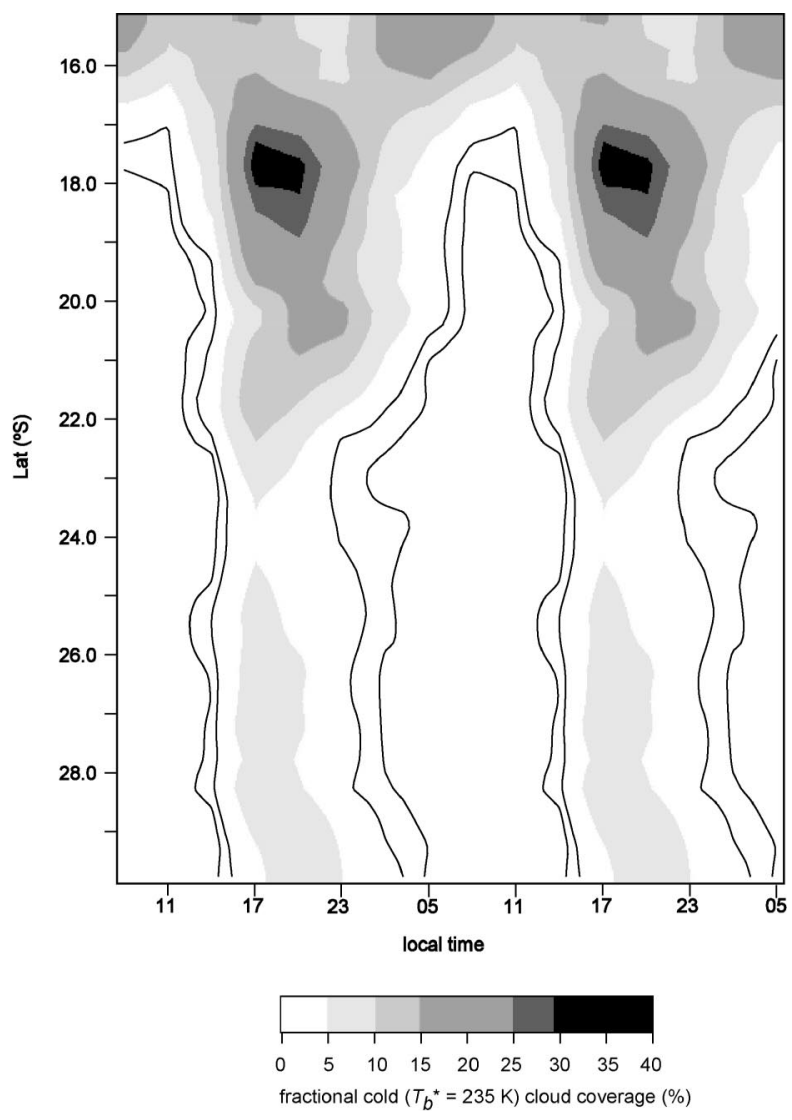

FIG. 3. Time-latitude diagram of diurnal cycle of fractional cold $\left(T_{b}^{*}=235 \mathrm{~K}\right)$ cloud coverage $F^{*}$ along $68^{\circ} \mathrm{W}$ between $15^{\circ}$ and $30^{\circ} \mathrm{S}$ during DJF (avg 1983-91). Shading indicates values of $F^{*}>5 \%$ (see scale below). Contour lines indicate $1 \%$ and $2 \%$, respectively. Data are from Garreaud and Wallace (1997).

interested in achieving the best possible regional match between the fraction of days with cold cloud coverage $F^{*}$ and rain gauge-based precipitation measurements from the central Andes, we performed a series of tests with varying thresholds $T_{b}^{*}$, to come up with the best possible precipitation estimate (see section 3 ).

Monthly rain gauge totals from a network of stations in Peru, Bolivia, and Chile were extracted from an Andean precipitation database described in Vuille et al. (2000a,b). Data for Argentina was obtained from the Bianchi and Yañez (1992) database.

The large-scale tropospheric circulation was analyzed based on NOAA-Outgoing Longwave Radiation (NOAA-OLR) data (Liebmann and Smith 1996), and reanalysis fields produced by the National Centers for Environmental Prediction-National Center for Atmospheric Research (NCEP-NCAR), described in detail in Kalnay et al. (1996) and Kistler et al. (2001). The NCEP-NCAR reanalysis data consists of globally complete fields on a $2.5^{\circ}$ latitude $\times 2.5^{\circ}$ longitude grid, including all mandatory pressure levels from 1000 to $10 \mathrm{hPa}$ (humidity up to only $300 \mathrm{hPa}$ ), as well as the near-surface level (0.995 sigma). 


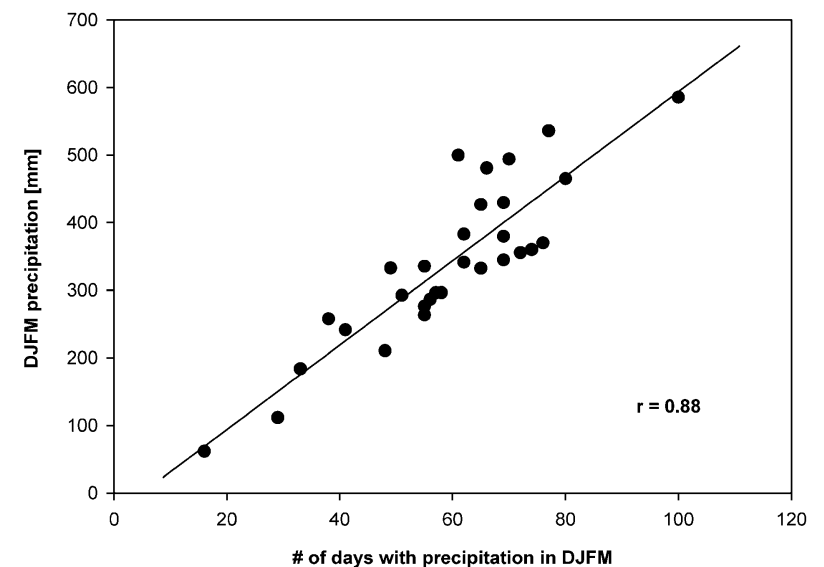

FIG. 4. Precipitation amount $(\mathrm{mm})$ vs number of days with precipitation in DJFM at station Cotacotani $\left(18.20^{\circ} \mathrm{S}, 69.23^{\circ} \mathrm{W} ; 4500 \mathrm{~m}\right)$ between 1960 and 1991, (except missing data for summer 1961/62).

\section{Relationship between precipitation and fractional cold cloud coverage $F^{*}$}

The value $F^{*}$, as defined here, only indicates on how many days per season $T_{b}$ reached a value below the threshold $T_{b}^{*}$ at either 1700 or 2100 local time, but it does not reveal how much below the threshold or for how many hours. Hence we can not directly apply a rain rate (e.g., $3 \mathrm{~mm} \mathrm{~h}^{-1}$; Arkin and Meisner 1987) to our estimate of $F^{*}$. However, as shown later, empirical evidence indicates that there is nonetheless a very close relationship between $F^{*}$ and precipitation amount on seasonal time scales. The main reason for this close association is related to the convective nature of precipitation on the Altiplano, which leads to a significant relationship between $T_{b}$ and precipitation of individual rainfall episodes (Garreaud 2000a). On seasonal timescales, the inherently episodic nature of precipitation on the Altiplano further strengthens this relationship, because it leads to a high correlation between seasonal precipitation amount and the number of days on which precipitation occurs. Figure 4 shows such an example based on $30 \mathrm{yr}$ of daily data from the station Cotacotani $\left(18.20^{\circ} \mathrm{S}, 69.23^{\circ} \mathrm{W} ; 4500 \mathrm{~m}\right)$ on the border between Chile and Bolivia. Evidently the seasonal precipitation amount is by and large a result of the number of days on which precipitation occurs $(r=0.88, p<0.001)$, a number that can easily be approximated by $F^{*}$, given that the threshold $T_{b}^{*}$ is correctly chosen.

\section{a. Spatial correlation}

To calculate the spatial correlation between precipitation amount and fractional cold cloud coverage $F^{*}$, seasonal precipitation totals for each grid box were determined by averaging all available rain gauge measurements within each $0.33^{\circ}$ latitude $\times 0.33^{\circ}$ longitude grid cell. Since the precipitation network in the central Andes is sparse and we relied on a high-resolution grid,

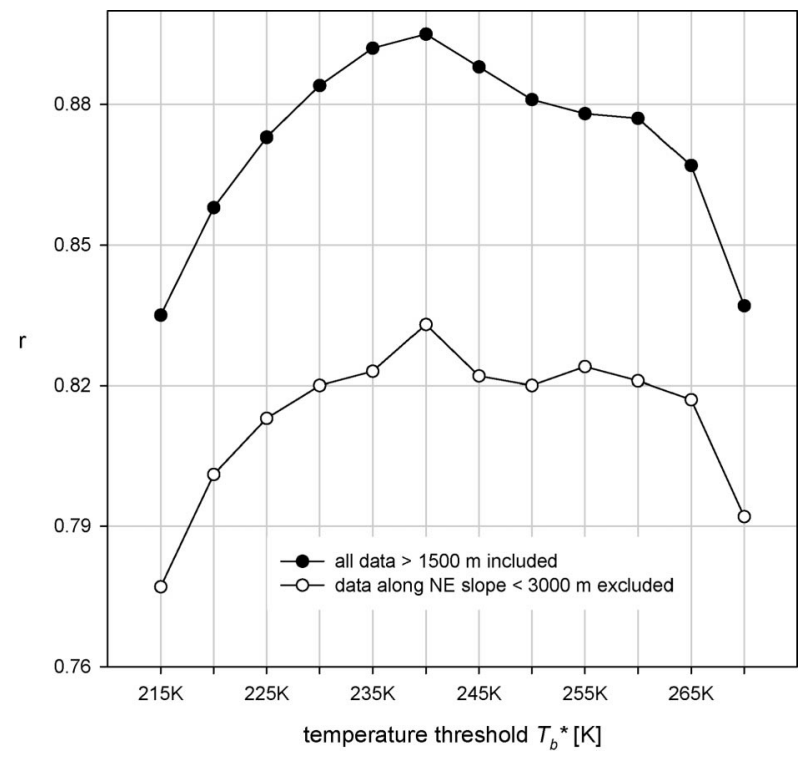

FIG. 5. Spatial correlation between seasonal rain gauge totals and fractional cold cloud cover $F^{*}$ as a function of $T_{b}^{*}$ based on a wet $(1983 / 84)$ and a dry $(1989 / 90)$ summer (DJFM) with stations $<3000$ $\mathrm{m}$ along the northeast slope included (open symbols) and excluded (filled symbols) from correlation analysis. Correlations are based on 174 and 162 (northeast slope excluded) data pairs, respectively.

only few cases occurred where more than one station fell within a certain grid box and many grid boxes remained empty.

The correlation between grid-cell precipitation and fractional cold cloud coverage $F^{*}$, was calculated several times using different temperature thresholds $T_{b}^{*}$ between 215 and $270 \mathrm{~K}$ (in 5-K increments), to determine which threshold yields the most accurate estimate of precipitation amount. Figure 5 shows the results from this analysis averaged over two extreme seasons, the wet summer 1983/84 and the dry summer 1989/90. The high correlations, ranging from 0.78 to 0.83 (all significant at $p<0.001$ ), point toward a close relationship between $F^{*}$ and precipitation amount. If data from the northeastern slope of the Andes, where precipitation does not exclusively fall in late afternoon and early evening hours (Fig. 3), are excluded from the analysis. the correlation is even higher ( $r$ value between 0.84 and 0.90 ). Between 230 and $260 \mathrm{~K}$ the correlation analysis yields a broad and quite flat maximum, indicating that it matters little which threshold $T_{b}^{*}$ is used. It is only below $230 \mathrm{~K}$ and above $260 \mathrm{~K}$ where the correlations start to drop off significantly. Even though the correlations vary little, a peak at $240 \mathrm{~K}$ is evident, which lead us to use this value as threshold for our subsequent analysis.

Table 3 lists the correlation coefficient $r$ and the slope of the regression $b$ between precipitation and $F^{*}$ (based on a threshold $T_{b}^{*}=240 \mathrm{~K}$ ) separately for each summer between 1983/84 and 1995/96. After 1996 insufficient station data were available to verify the relationship with 
TABLE 3. Correlation coefficient $r$ and spatial slope $b$ (in $\mathrm{mm} \%^{-1}$ ) of linear regression between seasonal fractional cold $\left(T_{b}^{*}=240 \mathrm{~K}\right)$, cloud coverage $F^{*}(\%)$, and seasonal rain gauge totals $(\mathrm{mm})$ during austral summer (DJFM). Rain gauge data from the NE slope $<3000$ $\mathrm{m}$ has been excluded. Only years 1983/84-1995/96, with sufficient rain gauge data for comparison ( $>25$ stations), are shown.

\begin{tabular}{ccr}
\hline \hline Year $($ DJFM $)$ & $r$ & $b$ \\
\hline $1983 / 84$ & 0.85 & 10.25 \\
$1984 / 85$ & 0.90 & 9.98 \\
$1985 / 86$ & 0.83 & 9.95 \\
$1986 / 87$ & 0.84 & 9.63 \\
$1987 / 88$ & 0.88 & 9.69 \\
$1988 / 89$ & 0.83 & 9.49 \\
$1989 / 90$ & 0.85 & 10.78 \\
$1990 / 91$ & 0.87 & 9.60 \\
$1991 / 92$ & 0.80 & 10.82 \\
$1992 / 93$ & 0.76 & 9.87 \\
$1993 / 94$ & 0.83 & 9.43 \\
$1994 / 95$ & 0.79 & 9.97 \\
$1995 / 96$ & 0.84 & 10.14 \\
\hline
\end{tabular}

$F^{*}$. The correlation varies between 0.76 and 0.90 (all significant at $p<0.001$ ), and the slope of the regression is on the order of $9.4-10.8 \mathrm{~mm} \%^{-1}$. This analysis thus confirms that the spatial relationship between $F^{*}$ and precipitation amount is stable over time. The quality of this relationship is quite remarkable given the high resolution of our grid, as correlations between precipitation amount and $F^{*}$ tend to increase with larger grid cell size (Richards and Arkin 1981).

\section{b. Temporal correlation}

Since the spatial correlation between precipitation and $F^{*}$ can not be used to deduce the quality of the temporal correlation at one specific site, it is worthwhile to investigate how this precipitation-cloud coverage relationship compares between individual stations throughout the central Andes. This is especially important since Fig. 5 indicated a significant increase in the spatial correlation when data from the northeast slope of the Andes were excluded. Figure 6 shows the temporal correlation between seasonal (DJFM) precipitation amount and $F^{*}$ at all grid cells where at least $10 \mathrm{yr}$ of data were available. The correlation is generally highest $(r>0.8)$ along the western cordillera north of $24^{\circ} \mathrm{S}$, while the values are somewhat lower ( $r$ values mostly in the order of $0.6-0.8$ ) further to the east. In the southernmost part of the central Andes data coverage is very poor, but the limited information available suggests that the temporal correlation is reasonably good ( $r$ values between 0.63 and 0.83$)$. The only region where this relationship apparently falls apart $(r$ values $<0.4)$ is to the northeast of the central Andes near the slope toward the Amazon basin. The most probable explanation for this poor relationship is the change in the diurnal cycle of convective activity (Fig. 3), and that the data used in this study (at 2100 and 0000 UTC) therefore does not capture the true number of days on which the temperature threshold

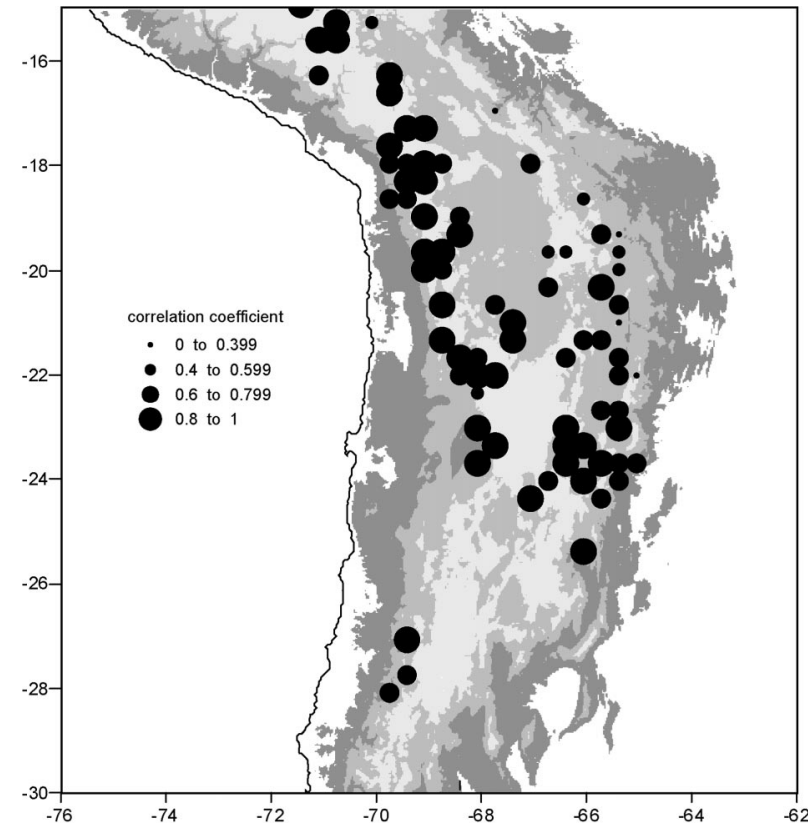

FIG. 6. Map of temporal correlation (1983-99) between seasonal (DJFM) fractional cold $\left(T_{b}^{*}=240 \mathrm{~K}\right)$ cloud cover $F^{*}$ and rain gauge data in the central Andes.

$T_{b}^{*}=240 \mathrm{~K}$ is reached. It is also possible that the threshold $T_{b}^{*}$, for which the correlation between precipitation and fractional cold cloud coverage $F^{*}$ is best, varies somewhat across the Andes. Overall however, the high correlations indicate that $F^{*}$ is not only a good measure of convective activity, but also provides a reasonably good estimate of precipitation amount over the western, southern, and even the eastern central Andes south of $22^{\circ} \mathrm{S}$.

\section{Interannual variability of convective cloudiness and precipitation}

Figure 7 shows four typical patterns of DJFM fractional cold $\left(T_{b}^{*}=240 \mathrm{~K}\right)$ cloud coverage $F^{*}$ as standardized departures from the long-term mean (198399). 1983/84 (Fig. 7a) and 1997/98 (Fig. 7b) represent the typical case of a wet and dry year, respectively, where convective activity and precipitation amounts did indeed vary in phase throughout the Altiplano, consistent with the prevailing view that on interannual time scales the entire central Andes tend to show precipitation anomalies of the same sign. The only significant deviation from this pattern occurred in southwestern Peru in 1997/98 (Fig. 7b), probably associated with enhanced convective activity over the coastal Pacific region during the 1997/98 El Niño event. Similar patterns with anomalies of the same sign throughout the study region are apparent in 1986/87 (wet) and 1987/88, 1989/ 90, and 1991/92 (all dry), respectively (not shown).

The more frequent situation, however, consists of departures of opposite sign to the north and the south. In 

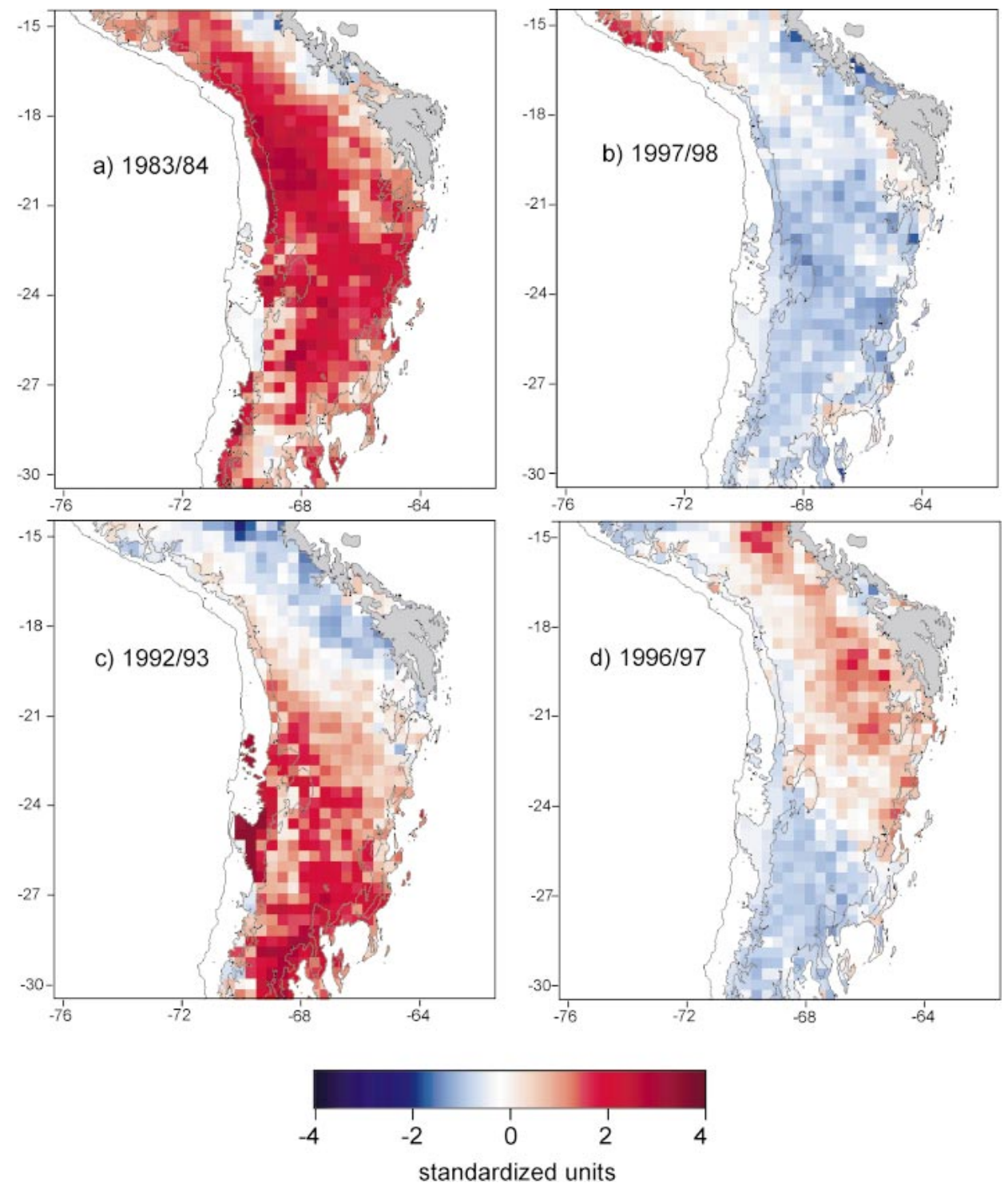

FIG. 7. Departure (standardized anomalies) of DJFM fractional cold $\left(T_{b}^{*}=240 \mathrm{~K}\right)$ cloud coverage $F^{*}$ from long-term mean (1983-99) in (a) 1983/84, (b) 1997/98, (c) 1992/93, and (d) 1996/97. Only results for regions $>1500 \mathrm{~m}$ are shown and northeast slope between 1500 and $3000 \mathrm{~m}$ is masked in gray. Black lines indicate 0-, 1500-, and 3000-m contour line.

1992/93, for example, wet conditions prevailed over the entire southern Altiplano, while it was dry to the north (Fig. 7c). In 1996/97 the situation was reversed with positive anomalies in the north but dry conditions to the south (Fig. 7d). Similar patterns are apparent in 1984/ $85,1985 / 86$, and $1990 / 91$ (wet to the north and dry in the south) and 1994/95 (dry to the north and wet in the south), respectively (not shown). However the N-S precipitation gradient (Fig. 1a) is never fully reversed, that is precipitation totals are still higher to the north, even in the situation shown in Fig. 7c. Although such an antiphasing between south and north has not been recognized before, it is consistent with results by Garreaud (2000a, see his Fig. 5), who shows that daily values of
$T_{b}$ in a grid box at $17.5^{\circ} \mathrm{S}$ are significantly correlated with $T_{b}$ elsewhere between $\sim 12^{\circ}$ and $21^{\circ} \mathrm{S}$, but not further to the south.

\section{a. REOF analysis}

To decompose the precipitation signal into its regional components with common modes of variance, we applied a rotated empirical orthogonal function (REOF) based on the correlation matrix of the standardized seasonal fractional cloud cover anomalies. While rotation leads to a relaxation of orthogonality and hence a loss of complete independence between the individual rotated EOFs, it helps to avoid problems with subdomain 

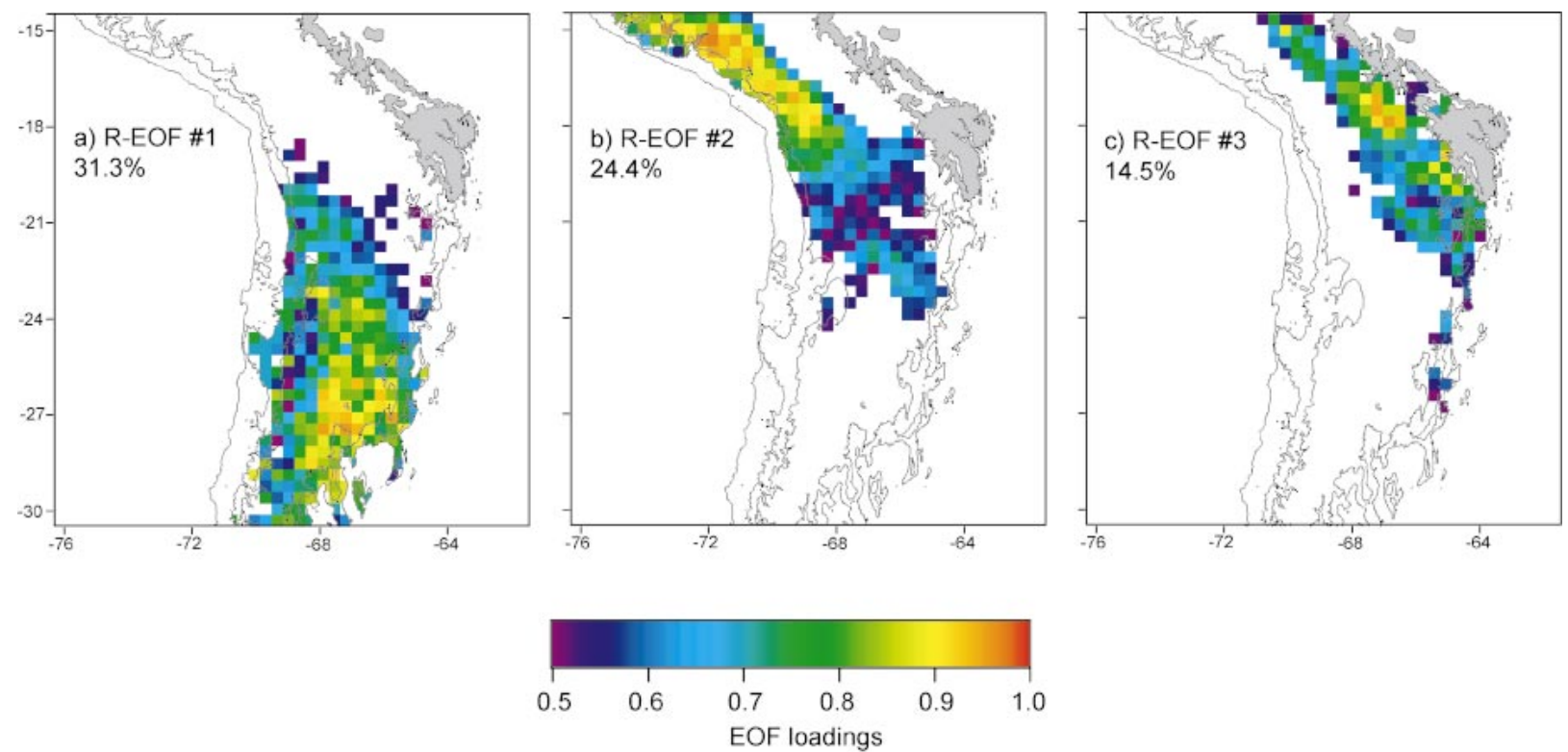

FIG. 8. (a) The first REOF 1 of fractional cold $\left(T_{b}^{*}=240 \mathrm{~K}\right)$ cloud coverage $F^{*}$ in the central Andes. Percentage indicates total variance explained. Only loadings $\geq 0.5$ for regions $>1500 \mathrm{~m}$ are shown and northeast slope between 1500 and $3000 \mathrm{~m}$ is masked in gray. Black lines indicate 0-, 1500-, and 3000-m contour line. (b)-(c) As in (a) but for REOFs 2-3.

instability and generally leads to modes of variability, which are physically more meaningful (Richman 1986). Three modes were well resolved based on the criterion of North et al. (1982) and retained for Varimax rotation (Richman 1986). Those three leading rotated modes explain $31.3 \%, 24.4 \%$, and $14.5 \%$ of the total variance, respectively. Their eigenvectors reveal a nice spatial separation with high loadings in the south (REOF 1),

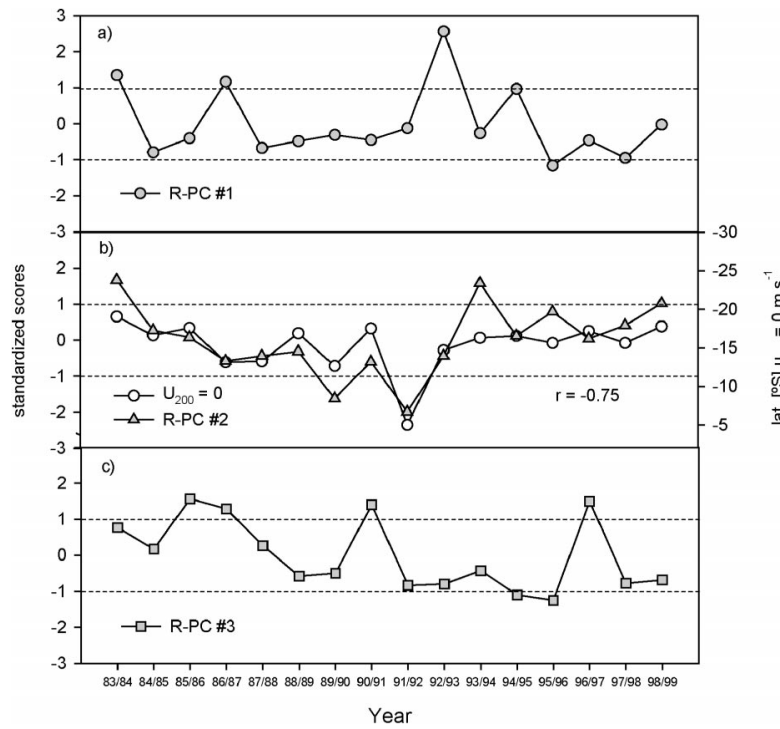

FIG. 9. (a) The first RPC 1 of DJFM fractional cold $\left(T_{b}^{*}=240 \mathrm{~K}\right)$ cloud coverage $F^{*}$. (b) As in (a) but for RPC 2. White symbols indicate average DJFM latitudinal position of $0 \mathrm{~m} \mathrm{~s}^{-1} 200-\mathrm{hPa}$ zonal wind component at $70^{\circ} \mathrm{W}$ (scale is reversed and plotted on right axis). (c) As in (a) but for RPC 3. northwest (REOF 2), and northeast (REOF 3), respectively (Fig. 8). The related principal components time series are shown in Fig. 9. Since REOF 3 exhibits highest loadings in the northeast close to the region where the diurnal cycle of convective activity is altered (Fig. 3 ) and the correlation with precipitation deteriorates considerably (Fig. 6), this mode was not included in further analysis. We do not feel confident in interpreting REOF 3 as a representative mode of precipitation variability in this region.

\section{b. Analysis of vertical cross sections}

Since a number of studies have pointed out that the upper-tropospheric circulation aloft the central Andes exerts the primary control on precipitation variability on all time scales, it is of considerable interest to see whether this is indeed the case for the two remaining modes REOF 1 and 2. We used regression analysis to investigate the atmospheric circulation over both the REOF 1 and REOF 2 domains. The regression fields presented in Figs. 10 and 11 show the local NCEPNCAR wind field and humidity anomalies in pressurelatitude (along $65^{\circ} \mathrm{W}$ ) and pressure-longitude cross sections (along $27.5^{\circ}$ and $17.5^{\circ} \mathrm{S}$ ) associated with a unit anomaly in the reference time series (principal components). The use of the rather coarse NCEP-NCAR reanalysis data to study mesoscale circulation in a region of high topographic relief may be somewhat questionable. However, Garreaud (2000a) has shown that the NCEP-NCAR reanalysis and near-surface in situ measurements of mixing ratio in the central Andes correlate reasonably well and that the reanalysis data captures 

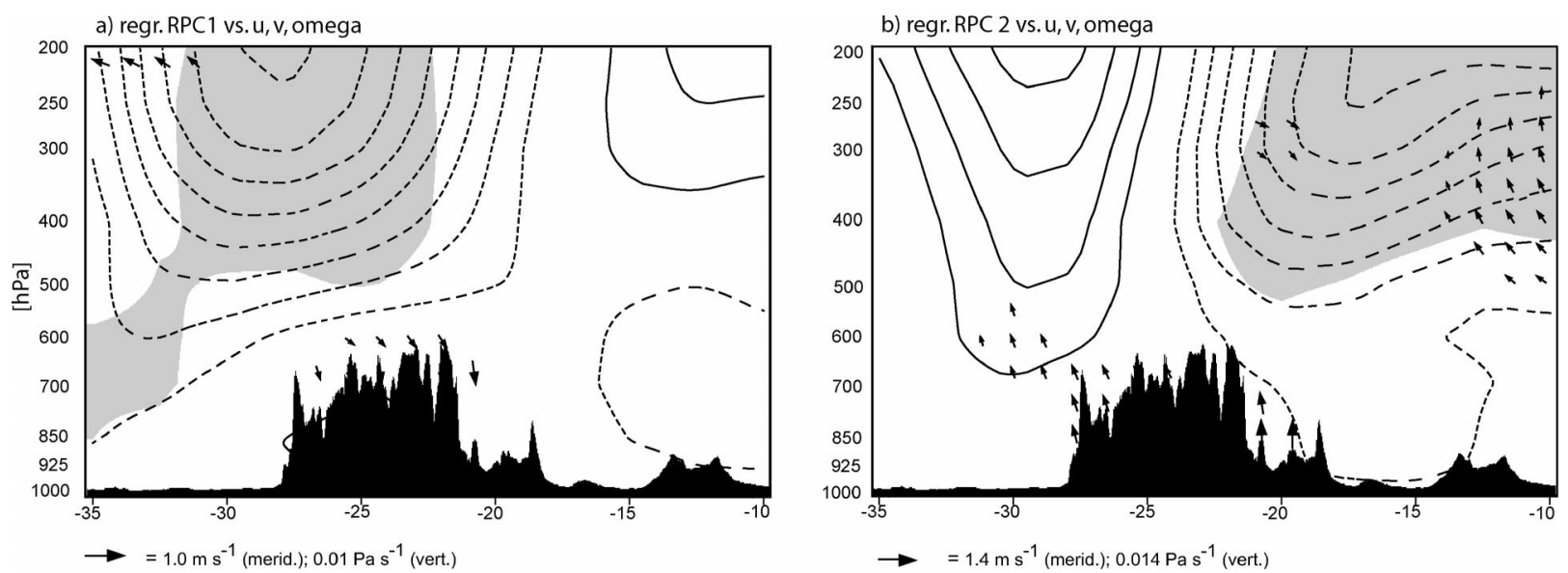

FIG. 10. (a) Pressure-latitude cross section to the east of the Andes $\left(65^{\circ} \mathrm{W}\right.$, between $35^{\circ}$ and $\left.10^{\circ} \mathrm{S}\right)$ of RPC 1 regressed upon NCEP-NCAR reanalysis zonal and meridional wind and vertical velocity. Wind vectors indicate meridional $\left(\mathrm{m} \mathrm{s}^{-1}\right)$ and vertical velocity anomalies $\left(\mathrm{Pa} \mathrm{s}^{-1}\right)$ associated with a unit anomaly of the RPC 1 time series. Vectors are only plotted where the correlation between either meridional wind or vertical velocity component and RPC 1 is significant at $p \leq 0.05$. Reference vector is given below. Contour lines indicate zonal wind speed anomalies; contour interval is $0.25 \mathrm{~m} \mathrm{~s}^{-1}$ per std dev; zero-contour line is omitted and negative contours are dashed. Gray shading indicates regions where the correlation between zonal wind and RPC 1 is significant at $p \leq 0.05$. Black area indicates Andean topography. (b) As in (a) but for RPC 2 .

most of the intraseasonal variability in near-surface humidity. Hardy et al. (2003) have shown that NCEPNCAR 400-500-hPa temperature in a grid box centered at $17.5^{\circ} \mathrm{S}, 70^{\circ} \mathrm{W}$ closely correlates with local air temperature measured on the summit of Sajama volcano $\left(18.1^{\circ} \mathrm{S}, 68.9^{\circ} \mathrm{W} ; 6542 \mathrm{~m}\right)$ on seasonal-to-interannual time scales. Nieto Ferreira et al. (2003) provide evidence for a close resemblance between observed and reanalyzed daily fluctuations of the low-level meridional wind to the east of the central Andes. Finally, Aceituno and Montecinos (2000) have reported that the reanalysis captures the general structure of the easterly moisture flux with a maximum at $500 \mathrm{hPa}$ over the Altiplano, although it underestimates its intensity. All this evidence leads us to believe that the reanalysis fields do indeed capture the essential features of the atmospheric circulation, at least in low levels to the east of the Andes and in the middle and upper troposphere.

The regression fields in Fig. 10 indeed indicate that easterly (westerly) upper- and midtropospheric wind anomalies dominate during wet (dry) summers over both the REOF $1\left(\sim 22^{\circ}\right.$ to $\left.35^{\circ} \mathrm{S}\right)$ and the REOF 2 domain $\left(\sim 10^{\circ}\right.$ to $\left.22^{\circ} \mathrm{S}\right)$. In both cases significant anomalous upper-air flow is limited to the region aloft its own a) regr. RPC 1 vs. u, vomega, q@ $27.5^{\circ} \mathrm{S}$

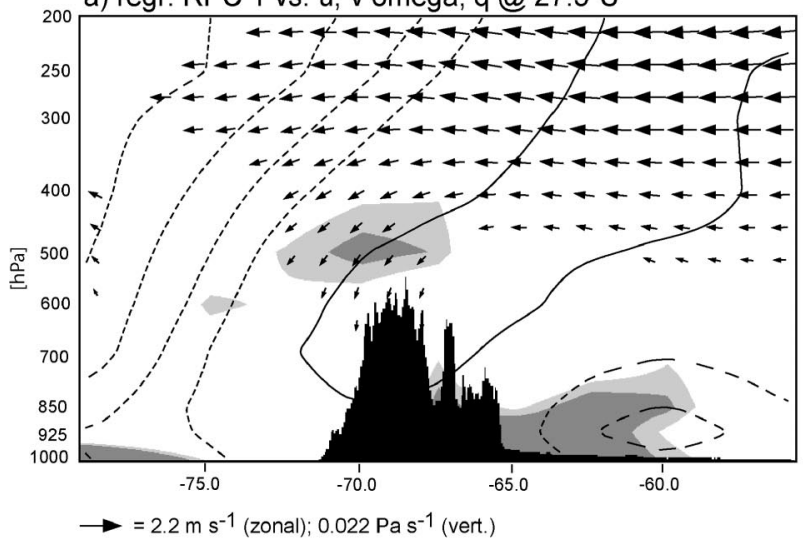

b) regr. RPC 2 vs. u, v, omega, q @ $17.5^{\circ} \mathrm{S}$

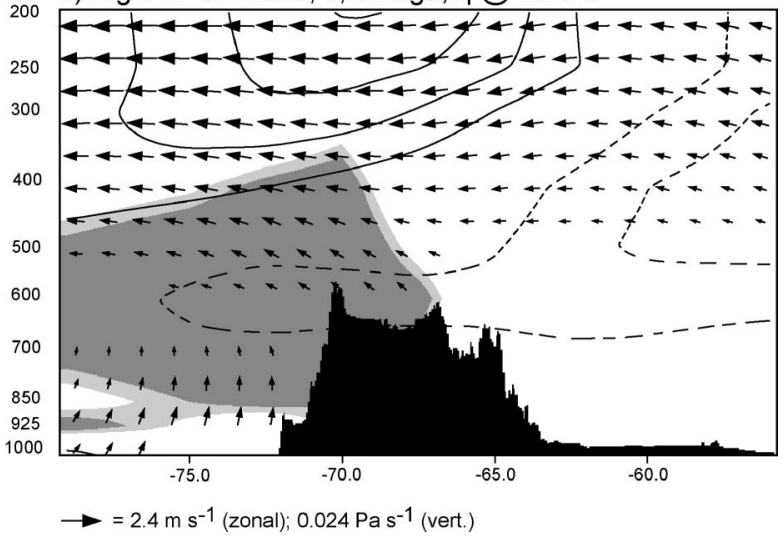

FIG. 11. (a) Pressure-longitude cross section at $27.5^{\circ} \mathrm{S}$ of RPC 1 regressed upon NCEP-NCAR reanalysis zonal and meridional wind, vertical velocity, and specific humidity. Wind vectors indicate zonal $\left(\mathrm{m} \mathrm{s}^{-1}\right)$ and vertical velocity anomalies $\left(\mathrm{Pa} \mathrm{s}^{-1}\right)$ associated with a unit anomaly of the RPC1 time series. Vectors are only plotted where the correlation between either zonal wind or vertical velocity component and RPC 1 is significant at $p \leq 0.05$. Reference vector is given below. Contour lines indicate meridional wind speed anomalies; contour interval is $0.2 \mathrm{~m} \mathrm{~s}^{-1}$ per std dev; zero contour line is omitted and negative contours are dashed. Dark (light) gray shading indicates regions where the correlation between specific humidity and RPC 1 is significant at $p \leq 0.05(0.1)$. Note that specific humidity data only extends up to $300 \mathrm{hPa}$. Black area indicates Andean topography. (b) As in (a) but for RPC 2 at $17.5^{\circ} \mathrm{S}$. 

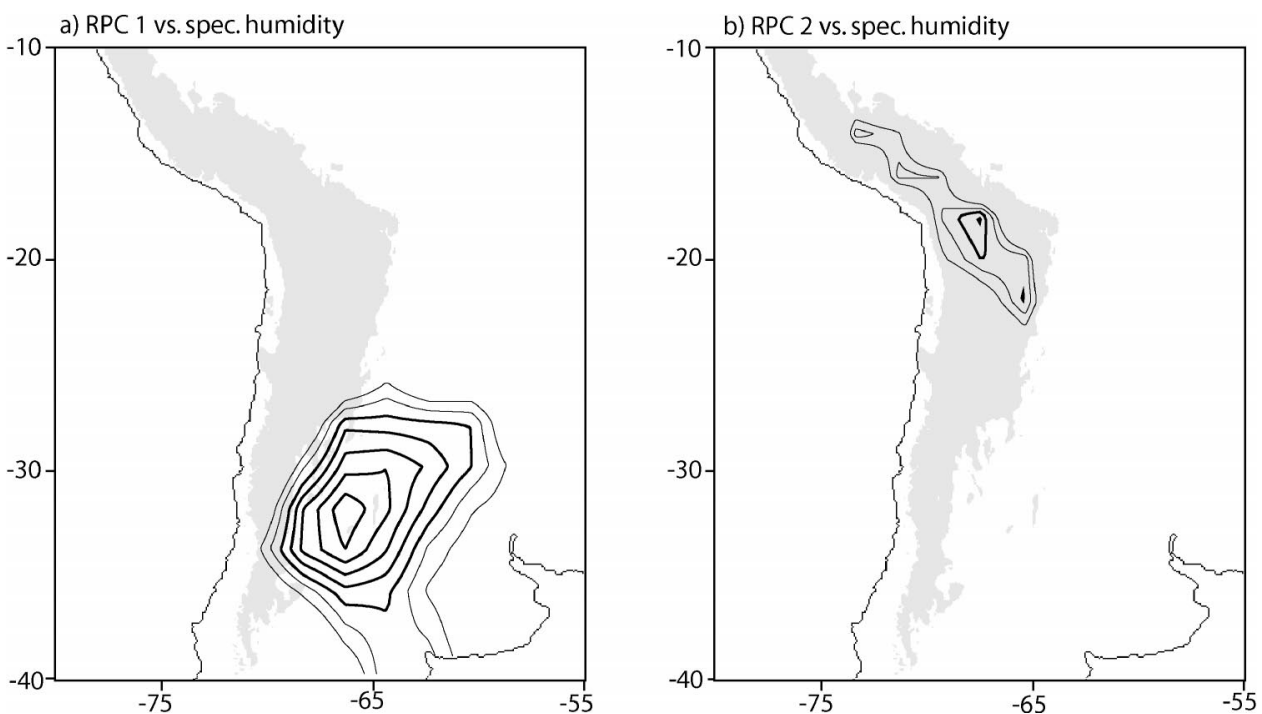

FIG. 12. (a) Correlation of RPC 1 with NCEP-NCAR near-surface (0.995 sigma level) specific humidity. Only contours $\geq 0.4$ over the continent are shown. Contour interval is 0.05 . Correlations $\geq 0.5$ (significant at $p<0.05$ ) are shown as bold lines. Shading indicates Andean topography $>1500 \mathrm{~m}$. (b) As in (a) but for RPC 2.

domain, while a complete although insignificant sign reversal of the upper-air wind anomalies occurs over the neighboring domain. This configuration provides the most likely scenario to explain the apparent antiphasing of wet and dry conditions as seen in Figs. 7c and 7d. It follows that the characterization of precipitation variability in the central Andes requires knowledge not only of the sign and strength but even more so of the exact location and extent of the anomalous flow. This notion, consistent with the results by Garreaud and Aceituno (2001), is illustrated by correlating rotated principal component 2 (RPC 2) with the mean DJFM latitude of the southernmost limit of easterly winds (DJFM $u_{200}=$ $0 \mathrm{~m} \mathrm{~s}^{-1}$ ) at $70^{\circ} \mathrm{W}$. The resulting $r$ value of -0.75 (Fig. $9 \mathrm{~b})$ is larger than that between RPC 2 and the mean 200-hPa zonal flow aloft ( $r=-0.67$, not shown). This result can be interpreted in the sense that the farther south the seasonal expansion of the upper-air easterlies reaches, the wetter the summer in the REOF 2 domain will be. Meridional wind and vertical velocity anomalies on the other hand do not appear to be closely related to convective activity in either of the two domains.

The pressure-longitude cross sections in Fig. 11 confirm the easterly/wet-westerly/dry relationship at both $27.5^{\circ} \mathrm{S}$ for REOF 1 and at $17.5^{\circ} \mathrm{S}$ for REOF 2 . However there appears to be a fundamental difference in the connection between convective activity in the central Andes and low-level moisture availability in the lowlands to the east between the two domains. At $27.5^{\circ} \mathrm{S}$ convective activity in the central Andes is significantly correlated with specific humidity in the lower troposphere to the east of the Andes (Fig. 11a) suggesting that changes in the moisture source region to the east might influence precipitation variability in the Andes. Farther to the north at $17.5^{\circ} \mathrm{S}$ such an influence is not at all apparent Here enhanced convective activity is associated with easterly wind anomalies, decreased subsidence over the eastern Pacific and significantly increased specific humidity over the western cordillera and farther downstream to the west of the Andes (Fig.11b). There is however no apparent connection with moisture changes in the source region to the east. A correlation analysis between near-surface ( 0.995 sigma level) specific humidity and RPC 1 and RPC 2, confirms the notion that precipitation variability in the REOF 1 domain is influenced by low-level moisture fluctuations to the east, while this is not the case in the REOF 2 region (Fig. 12). RPC 2 is significantly correlated with near-surface specific humidity over the northern Altiplano (the domain of its eigenvector REOF 2), but not elsewhere (Fig. $12 \mathrm{~b}$ ). This is consistent with previous studies showing that intraseasonal moisture variability in the northern part of the central Andes is not directly related to humidity fluctuations in the lowlands to the east (Garreaud 2000a). Our results indicate that the same is also true on interannual time scales. For the dry southern region of the central Andes however, moisture fluctuations in the lowlands to the southeast appear to be very relevant (Fig.12a). Here the interannual variability of the water vapor content in the source region to the east is almost 3 times as large as farther north in the source region of REOF $2 .{ }^{1}$ This might explain why there is such a high correlation between convective activity in the REOF 1

\footnotetext{
${ }^{1}$ The standard deviation of the DJFM near-surface specific humidity between 1983 and 1999 is $0.36 \mathrm{~g} \mathrm{~kg}^{-1}$ at $18.1^{\circ} \mathrm{S}, 65.6^{\circ} \mathrm{W}$ and $0.99 \mathrm{~g} \mathrm{~kg}^{-1}$ at $31.4^{\circ} \mathrm{S}, 65.6^{\circ} \mathrm{W}$ (location of maximum correlation in Fig. 12a).
} 
a) regr. RPC 1 vs. $200 \mathrm{hPa}$ geop. H, u, v

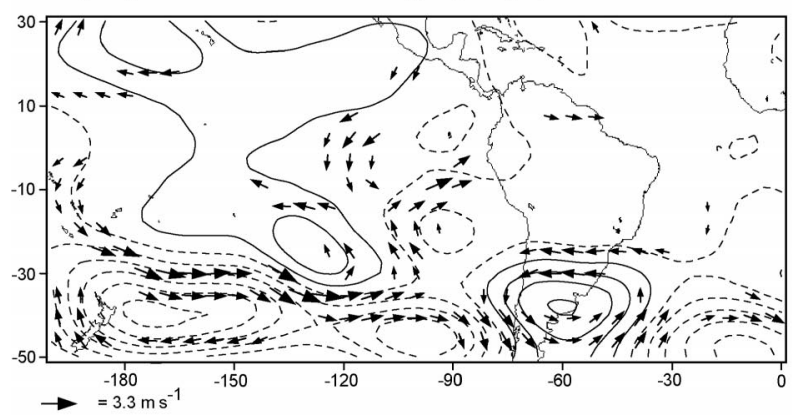

c) regr. RPC 2 vs. $200 \mathrm{hPa}$ geop. H, u, v

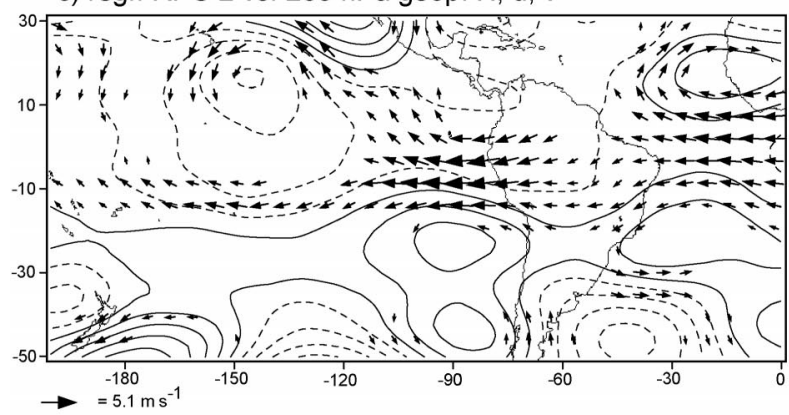

b) regr. RPC 1 vs. $200 \mathrm{hPa}$ u, v, OLR

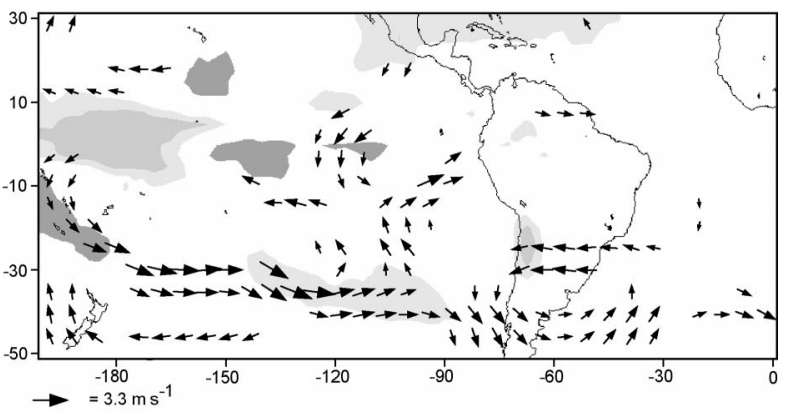

d) regr. RPC 2 vs. $200 \mathrm{hPa}$ u, v, OLR

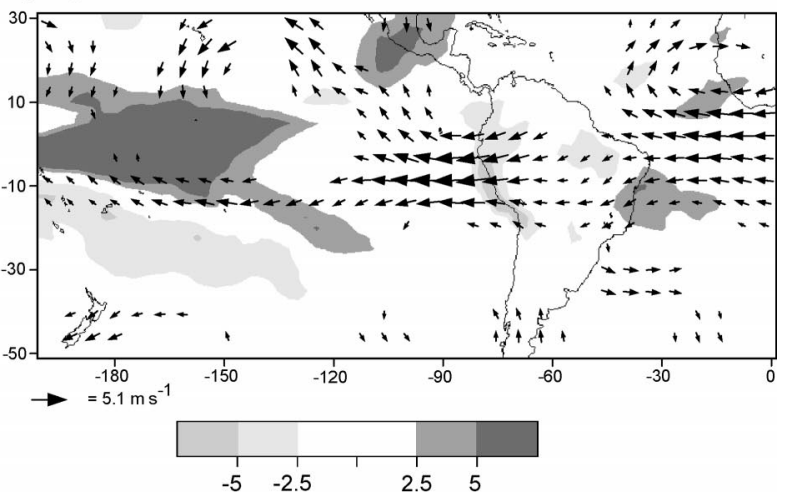

FIG. 13. (a) RPC 1 regressed upon DJFM 200-hPa NCEP-NCAR geopotential height and wind. Wind field is only plotted where the correlation between either zonal or meridional wind component and RPC 1 is significant at $p \leq 0.05$. Scale for wind vector (in $\mathrm{m} \mathrm{s}^{-1}$ per std dev) is shown below. Contour interval is 5 gpm per std dev; negative contours are dashed. (b) As in (a) but for NOAA-interpolated OLR and 200-hPa wind. Shading indicates OLR values above (below) $2.5(-2.5) \mathrm{W} \mathrm{m}^{-2}$ per std dev (see scale below). (c) As in (a) but for RPC 2. (d) As in (b) but for RPC 2.

domain and near-surface humidity fluctuations in the moisture source region to the southeast. Interannual variability in moisture content to the east of the central Andes in turn is influenced by variations in the strength of the Andean low-level jet (ALLJ), a conveyor belt which transports warm, moist air from the Amazon basin toward subtropical latitudes (e.g., Saulo et al. 2000; Vernekar et al. 2003; Marengo et al. 2002), but also by extratropical cold air incursions (e.g., Garreaud 2000b). The weak but insignificant negative correlation between convective activity in the REOF1 domain and the lowlevel meridional flow to the east of the Andes (Fig. 11a) suggests such a possible relationship with interannual variations in the intensity of the ALLJ. An in-depth analysis of the potential influence of the ALLJ on convection and precipitation in the southernmost central Andes, however, is beyond the scope of this paper and will be the focus of future work.

\section{c. Large-scale analysis}

To further investigate the causal relationship between the dominant modes of convective activity and the largescale atmospheric circulation we regressed the time series of RPC 1 and RPC 2 upon DJFM OLR, and both 200-hPa NCEP-NCAR geopotential height and wind fields. The regression patterns of the two modes do not share much in common, except that they both show significant easterly wind anomalies associated with wet conditions aloft the region of highest EOF loadings (Fig. 13). Consistent with the results from the analysis of vertical cross sections the large-scale regression fields indicate that the upper-air zonal flow is crucial in determining whether conditions are wet or dry in both regions. The regression field of RPC 1 shows significant OLR anomalies over the Andes between $20^{\circ}$ and $30^{\circ} \mathrm{S}$, indicative of enhanced convective activity and consistent with the results based on ISCCP imagery (Fig. 13b). Interestingly the most significant anomalies in geopotential height and wind field occur over the Southern Hemisphere midlatitudes, with an anticyclonic anomaly centered over southeastern South America (Fig. 13a). Projecting the anomaly on to the mean flow shows that this feature can be interpreted as a southward displacement of the Bolivian high. The associated relaxation of the upper-air westerly winds (easterly anomalies) allows episodic easterly transport of humid air toward the subtropical Andes. A similar pattern has been identified as one of the leading modes related to wet conditions in the central Andes on intraseasonal time scales (Vuille et al. 1998) and has been attributed to Rossby wave dispersion from the Southern Hemisphere extratropics, 
influencing the positioning of the Bolivian high (Garreaud 1999; Lenters and Cook 1999). Although the influence of Rossby wave activity on the intensity and strength of the Bolivian high is commonly assumed to be strongest on intraseasonal time scales, our results suggest that such a forcing also acts as a primary control on precipitation variability on interannual time scales for the southernmost part of the central Andes. This assumption is reasonable since precipitation in much of the REOF 1 domain is very sporadic and the seasonal totals (50-200 mm; Fig. 1a) are based on a few rainfall events per summer only. Hence the interannual signal must be strongly influenced by intraseasonal variability.

The regression field of RPC 2 on the other hand reveals circulation anomalies which are largely tropical in nature. OLR anomalies show negative departures, indicative of enhanced convective activity and precipitation, along the entire tropical Andes between $10^{\circ} \mathrm{N}$ and $20^{\circ} \mathrm{S}$ (Fig. 13d). These anomalies are caused by a significant enhancement of the upper-air easterly flow over the entire tropical Pacific-South American domain and in particular aloft the Andes. At its southern border these easterly anomalies (weakened upper-air westerly winds) are in geostrophic balance with reduced meridional baroclinicity over the eastern Pacific, caused by cooling at low and warming at subtropical latitudes (Fig. $13 \mathrm{c})$, consistent with the mechanism put forward by Garreaud and Aceituno (2001). Large OLR anomalies extend over the central equatorial Pacific and the South Pacific convergence zone (SPCZ) (Fig. 13d). All of these features are consistent with the interannual regression field derived from an Altiplano convective index by Garreaud and Aceituno (2001). In general this pattern is reminiscent of the atmospheric response to a La Niña event, known to cause positive precipitation anomalies in the Altiplano and closely resembles the ENSO-related anomalies presented by Yulaeva and Wallace (1994). Correlation of this mode with sea surface temperature anomalies (SSTAs) reveals the typical ENSO tongue, with negative correlations extending from the west coast of South America across the tropical Pacific to the date line, and positive correlations to the north and south (not shown).

\section{Summary and conclusions}

Our analysis, based on twice-daily ISCCP-B3 reduced resolution radiance data corrected for limb-darkening effects and in situ rain gauge measurements, indicates that the fractional cold cloud coverage $F^{*}$ derived from the ISCCP-B3 data is a reasonably good proxy for summertime convective activity and precipitation over most of the central Andes. The correlation between $F^{*}$ and precipitation amount is highest when a temperature threshold $T_{b}^{*}=240 \mathrm{~K}$ is used and applies everywhere, except over the northeastern portion of the central Andes. The analysis of $16 \mathrm{yr}(1983 / 84-1998 / 99)$ of data indicates that the prevailing view of precipitation de- partures varying in phase throughout the entire Altiplano needs to be revised. While some years show precipitation anomalies of the same sign along the entire central Andes between $15^{\circ}$ and $30^{\circ} \mathrm{S}$, more often the north and the south are out of phase. A REOF analysis confirms this notion yielding three spatially separated modes in the south, the northwest, and the northeast.

Regression analysis indicate that the upper-air zonal flow is the main control on precipitation anomalies in both the northern and southern part of the central Andes, with an anomalous easterly flow aloft favoring wet conditions and westerly flow producing dry conditions. If these wind anomalies are centered over the central part of the Altiplano and extend far enough north and south, the entire Altiplano will behave more or less coherently. This is consistent with many previous studies, but our results further indicate that these wind anomalies do not always extend over the entire area from $15^{\circ}$ to $30^{\circ} \mathrm{S}$, thereby causing wet conditions in the north and dry conditions to the south or vice versa. Hence besides the sign and the strength of the upper-air zonal flow, its exact location and extent are equally important to determine the spatial pattern of precipitation anomalies in the central Andes.

The regression of the principal component time series upon 200-hPa geopotential height, wind, and OLR data indicates that interannual variability of convective activity and precipitation is caused by two different mechanisms. The southern central Andes receive above-average precipitation in association with a Bolivian high displaced anomalously far south. The intensity and positioning of the anomalous anticyclone is influenced by Rossby wave dispersion from the Southern Hemisphere extratropics. This pattern is similar to a previously presented leading mode of atmospheric circulation, responsible for precipitation variability in the central Andes on intraseasonal time scales. Since precipitation in the dry southern central Andes is inherently episodic and the seasonal totals $(50-200 \mathrm{~mm})$ are based on a few rainfall events per summer only, it is reasonable to assume that the interannual signal is strongly influenced by intraseasonal variability. Further north interannual variability in convective activity and precipitation is largely of tropical nature. Wet summers are related to enhanced upper-air easterly wind anomalies aloft, with the winds in geostrophic balance with the reduced meridional baroclinicity over the eastern Pacific, caused by cooling at low and warming at subtropical latitudes. Given the linear nature of our analysis the pattern during dry summers is essentially reversed. Hence the circulation anomalies are reminiscent of the atmospheric response to ENSO events and in good agreement with the previously reported mechanism causing ENSO-related precipitation departures in the central Andes (Garreaud and Aceituno 2001).

Besides the different atmospheric circulation mechanisms causing wet and dry summers in the regions of REOF 1 and 2, it appears as if the importance of mois- 
ture fluctuations in the lowlands to the east is also a distinguishing factor between the two domains. RPC 2 is significantly correlated with near-surface specific humidity in the northern central Andes, that is, in the domain of its own eigenvector REOF 2, but not elsewhere. In particular there is no correlation with moisture fluctuations in the source region to the east, consistent with results from previous studies on intraseasonal time scales. For the dry southern region of the central Andes however, moisture fluctuations in the lowlands to the southeast appear to be very relevant. Here wet conditions are accompanied by an enhanced specific humidity in the lower troposphere to the east of the Andes. The reason why low-level moisture fluctuations to the east matter for the southern but not for the northern central Andes is not entirely clear, but may be related to the fact that the interannual variability of the water vapor content in the source region to the east is almost 3 times larger in the south at $31^{\circ} \mathrm{S}$ than farther north in the source region of REOF 2 at $18^{\circ} \mathrm{S}$.

Acknowledgments. We wish to thank Robert Joyce for his review and for providing us with the algorithm for the zenith-angle correction. Rene Garreaud is gratefully acknowledged for his helpful comments on this manuscript and for contributing the data for Fig. 3. Yelena Yarosh provided us with the information on weekly GOES subsatellite longitude positions. Ricardo Villalba and Martin Trauth contributed the precipitation data for Argentina. Two anonymous reviewers helped us with inspiring comments and suggestions that lead to a substantial improvement of this manuscript. ISCCP-B3 data were obtained from the NASA Langley Research Center Atmospheric Sciences Data Center. NCEP-NCAR reanalysis and OLR data were provided by NOAA-CIRES Climate Diagnostics Center. This study was funded by NSF Grant ATM-0214285.

\section{REFERENCES}

Aceituno, P., 1988: On the functioning of the Southern Oscillation in the South American sector. Part I: Surface climate. Mon. Wea. Rev., 116, 505-524.

_ , and A. Montecinos, 1993: Circulation anomalies associated with dry and wet periods in the South American Altiplano. Preprints, Fourth Int. Conf. on Southern Hemisphere Meteorology and Oceanography, Hobart, Tasmania, Australia, Amer. Meteor. Soc., 330-331.

— , and — 1997: Meteorological field experiments in the South American Altiplano. Preprints, Fifth Int. Conf. on Southern Hemisphere Meteorology and Oceanography, Pretoria, South Africa, Amer. Meteor. Soc., 330-331.

— tiplano: Comparison of NCEP/NCAR reanalysis with upper-air observations during the Visviri field experiment. Preprints, Sixth Int. Conf. on Southern Hemisphere Meteorology and Oceanography, Santiago, Chile, Amer. Meteor. Soc., 412-413.

Adler, R. F., G. J. Huffman, D. T. Bolvin, S. Curtis, and E. J. Nelkin, 2000: Tropical rainfall distributions determined using TRMM combined with other satellite and rain gauge information. $J$. Appl. Meteor., 39, 2007-2023.

Arkin, P. A., and B. N. Meisner, 1987: The relationship between large- scale convective rainfall and cold cloud over the Western Hemisphere during 1982-84. Mon. Wea. Rev., 115, 51-74.

, and P. Xie, 1994: The Global Precipitation Climatology Project: First algorithm intercomparison project. Bull. Amer. Meteor. Soc., 75, 401-420.

Arnaud, Y., F. Muller, M. Vuille, and P. Ribstein, 2001: El NiñoSouthern Oscillation (ENSO) influence on a Sajama volcano glacier from 1963 to 1998 as seen from Landsat data and aerial photography. J. Geophys. Res., 106, 17 773-17 784.

Baker, P. A., and Coauthors, 2001: The history of South American tropical precipitation for the past 25,000 years. Science, 291, 640-643.

Bendix, J., S. Gaemmerler, C. Reudenbach, and A. Bendix, 2003: A case study of rainfall dynamics during El Niño/La Niña 1997/ 99 in Ecuador and surrounding areas as inferred from GOES-8 and TRMM-PR observations. Erdkunde, 57, 81-93.

Betancourt, J. L., C. Latorre, J. A. Rech, J. Quade, and K. A. Rylander 2000: A 22,000-yr record of monsoonal precipitation from northern Chile's Atacama desert. Science, 289, 1542-1546.

Bianchi, A. R., and C. E. Yañez, 1992: Las precipitaciones en el noroeste Argentino. Instituto Nacional de Technologia Agropecuaria. Estacion Experimental Agropecuaria, Salta, 383 pp.

Bradley, R. S., M. Vuille, D. R. Hardy, and L. G. Thompson, 2003: Low latitude ice cores record Pacific sea surface temperatures. Geophys. Res. Lett., 30, 1174, doi:10.1029/2002GL016546.

Ebert, E. E., M. J. Manton, P. A. Arkin, R. J. Allam, G. E. Holpin, and A. Gruber, 1996: Results from the GPCP algorithm intercomparison programme. Bull. Amer. Meteor. Soc., 77, 28752887.

Francou, B., M. Vuille, P. Wagnon, J. Mendoza, and J. E. Sicart, 2003: Tropical climate change recorded by a glacier in the central Andes during the last decades of the 20th century: Chacaltaya, Bolivia, $16^{\circ}$ S. J. Geophys. Res., 108, 4154, doi:10.1029/ 2002JD002959.

Fuenzalida, H. P., and J. Rutllant, 1987: Origen del vapor de agua que precipita en el Altiplano de Chile. Proc. Anales del II Congreso Interamericano de Meteorologia, Buenos Aires, Argentina, 6.3.1-6.3.4.

Garreaud, R. D., 1999: Multiscale analysis of the summertime precipitation over the central Andes. Mon. Wea. Rev., 127, 901921.

, 2000a: Intraseasonal variability of moisture and rainfall over the South American Altiplano. Mon. Wea. Rev., 128, 3337-3346. , 2000b: Cold air incursions over subtropical South America: Mean structure and dynamics. Mon. Wea. Rev., 128, 2544-2559. and J. M. Wallace, 1997: The diurnal march of convective cloudiness over the Americas. Mon. Wea. Rev., 125, 3157-3171.

__ , and P. Aceituno, 2001: Interannual rainfall variability over the South American Altiplano. J. Climate, 14, 2779-2789.

_- M. Vuille, and A. Clement, 2003: The climate of the Altiplano: Observed current conditions and mechanisms of past changes. Palaeogeogr., Palaeoclimatol., Palaeoecol., 194, 5-22.

Grosjean, M., I. Cartajena, M. A. Geyh, and L. Nunez, 2003: From proxy data to paleoclimate interpretation: The mid-Holocene paradox of the Atacama desert, northern Chile. Palaeogeogr., Palaeoclimatol., Palaeoecol., 194, 247-258.

Hardy, D. R., M. Vuille, C. Braun, F. Keimig, and R. S. Bradley, 1998: Annual and daily meteorological cycles at high altitude on a tropical mountain. Bull. Amer. Meteor. Soc., 79, 18991913.

_,$\ldots$, and R. S. Bradley, 2003: Variability of snow accumulation and isotopic composition on Nevado Sajama, Bolivia. $J$. Geophys. Res., 108, 4693, doi:10.1029/2003JD003623.

Huffman, G. J., and Coauthors, 1997: The Global Precipitation Climatology Project (GPCP) combined precipitation dataset. Bull. Amer. Meteor. Soc., 78, 5-20.

Janowiak, J. E., R. J. Joyce, and Y. Yarosh, 2001: A real-time global half-hourly pixel-resolution infrared dataset and its applications. Bull. Amer. Meteor. Soc., 82, 205-217.

Joyce, R., and P. A. Arkin, 1997: Improved estimates of tropical and 
subtropical precipitation using the GOES precipitation index. $J$. Atmos. Oceanic Technol., 14, 997-1011.

__ J. Janowiak, and G. Huffman, 2001: Latitudinally and seasonally dependent zenith-angle corrections for geostationary satellite IR brightness temperatures. J. Appl. Meteor., 40, 689-703.

Kalnay, E., and Coauthors, 1996: The NCEP/NCAR 40-Year Reanalysis Project. Bull. Amer. Meteor. Soc., 77, 437-471.

Kessler, A., 1974: Atmosphärische Zirkulationsanomalien and Spiegelschwankungen des Titicacasees. Bonn. Met. Abh., 17, 361372.

_- 1981: Wasserhaushaltsschwankungen auf dem Altiplano in Abhaengigkeit von der atmosphaerischen Zirkulation. Aachener Geographische Arbeiten, 14, 111-121.

Kistler, R., and Coauthors, 2001: The NCEP-NCAR 50-year reanalysis: Monthly means CD-ROM and documentation. Bull. Amer. Meteor. Soc., 82, 247-268.

Lenters, J. D., and K. Cook, 1999: Summertime precipitation variability over South America: Role of the large-scale circulation. Mon. Wea. Rev., 127, 409-431.

Liebmann, B., and C. A. Smith, 1996: Description of a complete (interpolated) outgoing longwave radiation dataset. Bull. Amer. Meteor. Soc., 77, 1275-1277.

— J. D. Glick, J. A. Marengo, V. E. Kousky, I. C. Wainer, and O. Massambani, 1998: A comparison of rainfall, outgoing longwave radiation, and divergence over the Amazon basin. J. Climate, 11, 2898-2909.

Marengo, J. A., 1995: Interannual variability of deep convection over the tropical South American sector as deduced from ISCCP C2 data. Int. J. Climatol., 15, 995-1010.

— , M. W. Douglas, and P. L. Silva Dias, 2002: The South American low-level jet east of the Andes during the 1999 LBA-TRMM and LBA-WET AMC campaign. J. Geophys. Res., 107, 8079, doi:10.1029/2001JD001188.

McCollum, J. R., and W. F. Krajewski, 1999: On the relationship between the GOES precipitation index and ISCCP dataset variables. J. Geophys. Res., 104, 31 467-31 476.

Morrissey, M. L., and J. S. Greene, 1993: Comparison of two satellitebased rainfall algorithms using Pacific atoll raingage data. $J$. Appl. Meteor., 32, 411-425.

Negri, A. J., R. F. Adler, E. J. Nelkin, and G. J. Huffman, 1994: Regional rainfall climatologies derived from Special Sensor Microwave Imager (SSM/I) data. Bull. Amer. Meteor. Soc., 75, $1165-1182$.

—_, E. N. Anagnostou, and R. F. Adler, 2000: A 10-yr climatology of Amazonian rainfall derived from passive microwave satellite observations. J. Appl. Meteor., 39, 42-56.

Nieto Ferreira, R., T. M. Rickenbach, D. L. Herdies, and L. M. V. Carvalho, 2003: Variability of South American convective cloud systems and tropospheric circulation during January-March 1998 and 1999. Mon. Wea. Rev., 131, 961-973.

North, G. R., T. L. Bell, R. F. Cahalan, and F. J. Moeng, 1982: Sampling errors in the estimation of empirical orthogonal functions. Mon. Wea. Rev., 110, 699-706.

Richards, F., and P. Arkin, 1981: On the relationship between satellite- observed cloud cover and precipitation. Mon. Wea. Rev., 109, 1081-1093.

Richman, M. B., 1986: Rotation of principal components. Int. J. Climatol., 6, 293-335.

Rossow, W. B., and R. A. Schiffer, 1991: ISCCP cloud data products. Bull. Amer. Meteor. Soc., 72, 2-20.

— , and — 1999: Advances in understanding clouds from ISCCP. Bull. Amer. Meteor. Soc., 80, 2261-2287.

Saulo, A. C., M. Nicolini, and S. C. Chou, 2000: Model characterization of the South American low-level flow during the 199798 spring-summer season. Climate Dyn., 16, 867-881.

Seltzer, G. O., D. T. Rodbell, and H. E. Wright, 2003: Late-quaternary paleoclimates of the southern tropical Andes and adjacent regions. Palaeogeogr., Palaeoclimatol., Palaeoecol., 194, 1-3.

Thompson, L., E. Mosley-Thompson, and B. J. Arnao, 1984: El NiñoSouthern Oscillation events recorded in the stratigraphy of the tropical Quelccaya ice cap, Peru. Science, 226, 50-52.

- and Coauthors, 1998: A 25,000-year tropical climate history from Bolivian ice cores. Science, 282, 1858-1864.

Todd, M., and R. Washington, 1999: A simple method to retrieve 3hourly estimates of global tropical and subtropical precipitation from International Satellite Cloud Climatology Program (ISCCP) D1 data. J. Atmos. Oceanic Technol., 16, 146-155.

Vernekar, A. D., B. P. Kirtman, and M. J. Fennessy, 2003: Low-level jets and their effects on the South American summer climate as simulated by the NCEP Eta Model. J. Climate, 16, 297-311.

Vuille, M., 1999: Atmospheric circulation over the Bolivian Altiplano during dry and wet periods and extreme phases of the Southern Oscillation. Int. J. Climatol., 19, 1579-1600.

— , and C. Ammann, 1997: Regional snowfall patterns in the high arid Andes. Climatic Change, 36, 413-423.

— D. R. Hardy, C. Braun, F. Keimig, and R. S. Bradley, 1998: Atmospheric circulation anomalies associated with 1996/1997 summer precipitation events on Sajama ice cap, Bolivia. J. Geophys. Res., 103, 11 191-11 204.

— R. S. Bradley, and F. Keimig, 2000a: Interannual climate variability in the central Andes and its relation to tropical Pacific and Atlantic forcing. J. Geophys. Res., 105, 12 447-12 460.

- — Ecuador and its relation to tropical Pacific and Atlantic sea surface temperature anomalies. J. Climate, 13, 2520-2535.

-, , R. Healy, M. Werner, D. R. Hardy, L. G. Thompson, and F. Keimig, 2003: Modeling $\delta^{18} \mathrm{O}$ in precipitation over the tropical Americas: 2. Simulation of the stable isotope signal in Andean ice cores. J. Geophys. Res., 108, 4175, doi:10.1029/2001JD002039.

Wagnon, P., P. Ribstein, B. Francou, and J. E. Sicart, 2001: Anomalous heat and mass budget of Glaciar Zongo, Bolivia, during the 1997-98 El Niño year. J. Glaciol., 47, 21-28.

Xie, P., and P. A. Arkin, 1997: Global Precipitation: A 17-year monthly analysis based on gauge observations, satellite estimates, and numerical model outputs. Bull. Amer. Meteor. Soc., 78, 25392558.

Yulaeva, E., and J. M. Wallace, 1994: The signature of ENSO in global temperature and precipitation fields derived from the microwave sounding unit. J. Climate, 7, 1719-1736. 